\title{
Bazaars and Video Games in India
}

\author{
Maitrayee Deka
}

\begin{abstract}
This article examines the history of video games in India through the lens of Delhi's electronic bazaars. As many gamers shifted from playing Atari Games in the 1980s to PlayStation in the 2000s, we see a change in the role that the bazaars play. Throughout the 1980s and 1990s, the bazaars were the crucial channels of smuggling video games into India. In the 2000s, the bazaars face competition from official channels. Increasingly, the branded showrooms and online market attract elite consumers who can afford to buy the latest original video game. I argue that, while in the twenty-first century, the electronic bazaars have seen a decline in their former clientele, they now play a new role: they have become open places through the circulation of "obsolete" video games, and the presence of a certain bazaari disposition of the traders. The obsolete games in the form of cartridge, cracked console, and second hand games connect video games to people outside the elite network of corporate and professional new middle class. This alongside the practice of bargaining for settling price creates dense social relationships between a trader and a consumer.
\end{abstract}

\section{Keywords}

India, video games, bazaars, obsolescence, openness, innovation

\section{Introduction}

The popularity of video games has been elusive in India. Video games appearing as a leisure time activity and the possibility to play a quick game on smartphones add to their casual nature. Even though there are fewer glorifications of video games either as a profession or as a mode of military training, the outreach of video games in the country cannot be ignored. Media reportage estimates the video gaming industry at ₹1500 crore in 2013 (Arora, 2014).

Maitrayee Deka, Department of Social and Political Sciences University of Milan Via Conservatorio, 7 Milan-20122.

E-mail: Maitrayee.deka@unimi.it 
The popularity of video games in India is not sudden. In the 1980s, Indian gamers played games such as Pac-Man on their home video game consoles. Atari 2600 and Game Boy were other popular franchises from that time. In the early years, a gift economy made TV consoles and later handheld games a part of Indian households. Many gamers in Delhi recollect that their earliest gaming experiences were on a console gifted by a relative settled abroad. Apart from the home consoles, arcade game was a popular gaming device. Usually the "mohalla" (neighborhood) cafes hosted "coinoperated" arcade games.

However, in the early decades what made video games a popular household item was the informal electronic markets. In the 1980s and 1990s, gamers remembered queuing up in front of the shops at Palika Bazaar to buy video games. In this article, I will analyze three informal electronic markets in Delhi, Lajpat Rai Market, Palika Bazaar, and Nehru Place, and build a history of video games through their transformations over time.

The presence of semi-legal goods, being boisterous and crowded, makes "bazaar" a suitable term to talk about the electronic markets (Fanselow, 1990; Geertz, 1963; Jain, 2007). ${ }^{1}$ Much like the traditional bazaars, in the contemporary bazaars in Delhi, economic and social life coincides. Alongside the search of profits and an exchange of money, the fact that trading is also a social activity makes the trade in the bazaar a distinct form of economic action. I spent 12 months in the bazaars between September 2012 and 2013, and then in January 2015. I interviewed close to 70 traders, three importers and approximately 30 gamers in the three markets. I went to other places such as Milestone in Okhla, and Hamleys in South Delhi to understand the other side of bazaar, the formal economy of gaming. Many of the vignettes in the article emerge from spontaneous conversation with the traders.

Tracing the growth of the video game industry through the electronic bazaars, we observe the history of video games is non-linear. "Obsolete" games do not go out of circulation. They exist in the markets in different ways. Although recently, the media archaeology literature analyzes the aesthetic and personal recall value attached to old media objects, obsoleteness in the bazaar extends beyond the materiality of the object to have complex relationship with market actors (Parikka, 2012). One of the ways in which old video games are available in the markets is by physically co-existing alongside the new. The earlier 8-bit and 16-bit games are "zombie-media," "living deads" that are still in circulation in an era of the PlayStation and Xbox. The obsolete also appropriate the new, for instance, the cracking of old video game consoles and making them play pirated versions of new games. And finally the old and the new exist in a circular temporality, where the new becomes the old, and the old becomes new if we look at practices of recycling. The presence of obsolete games in the different stages of assembling take away from the "aura" video games as a uniquely sophisticated "information product" while at the same time connecting it to gamers who prefer cheap games (Dyer-Witheford \& Sharman, 2005).

There is another attribute alongside obsoleteness that increasingly makes the electronic bazaars open places. This is to do with the bazaari disposition of the trader, gregarious, and incessantly bargaining to settle prices. In writing about the bazaars of 
Morocco and Indonesia, Clifford Geertz $(1963,1978)$ lays out the social nature of the bazaar via the search for information. Geertz (1978) observes in Morocco,

The search for information-laborious, uncertain, complex and irregular-is the central experience of life in the bazaar. Every aspect of the bazaar economy reflects that the primary problem facing its participants (that is, "bazaaris") is not balancing but finding out what they are... The main energy of the bazaari is directed toward combing the bazaar for usable signs, clues. (Geertz, 1978, p. 30)

The cues between the buyer and seller are played out against one another in the rituals of intensive bargaining. Even in the pasars of Indonesia, Geertz (1963) notices intricate bargaining practice, as much psychological as physically exhaustive to counter the information asymmetry/scarcity in the traditional markets in Modjokuto. The intense bargaining practices act as an important price setting mechanism in the electronic markets in Delhi as well. With the original products they have a standard price and price margin within which traders bargain. With most other products that are knock-offs, second-hands, and pirated, the prices are much more flexible and receptive to bargaining close to its buying price.

Apart from being the backbone of commercial transactions in the markets, bargaining practices bring out the social nature of the markets. Delhi's traders similar to the bazaaris of peasant markets in Morocco and Indonesia invest time and energy to scrutinize a buyer, the intended consequence of which is to have a successful market transaction but this also indirectly opens up a line of social interaction that cannot be limited to the commercial exchange alone. "Skill in bargaining-which includes as its elements a quick wit, a tireless persistence, and an instinctive shrewdness in evaluation men" is "what makes a good market trader" (Geertz, 1963, p. 33). Delhi's traders spin a web of jokes, trickery, and small conversation to get to the core of a commercial exchange, many a times establishing a personal relationship with the consumer.

The theme of obsoleteness and the social character of the bazaars recur in this article to build on the idea of the mass electronic markets as open places. Although an onslaught of diverse goods and people have been a part of the bazaars, it is only now that these traits stand out as the overall political and economic landscape of the country is changing. Post liberalization of the economy in the 1990s, we see a new lifestyle becoming dominant in the country championed by the new middle class (NMC). Leela Fernandes (2006) argues that the tendency of the NMC is to locate consumption as a site of individual strategies that are shaped by the privatization of public places and utilities. Communitarian places of grazing fields and playgrounds are getting increasingly replaced by high-rise apartments and fancy malls.

In such a scenario, the electronic bazaars is one of the few places where the mass is welcome and is not stigmatized for not being the "poster-child" of neoliberal India, the educated urban NMC, with their impeccable English and the love for global luxury brands (Fernandes \& Heller, 2006). Although the consumers coming to the bazaars are difficult to put in one income bracket, they emerge as a group when opposed to the elites in India, the NMC, corporates, the political and traditional landowning elites (Chatterjee, 2008; Saavala, 2010). The consumers in the bazaars include students who 
do not have money to buy brand new games. Other consumers include friends and acquaintances of the traders who know each other through the market. A popular group of consumers is young parents from small towns who are looking to buy their child a basic video game. A section of the consumers are young men who make their living out of the informal economy working as shop assistants and delivery boys. Finally, among the buyers of the bazaars are distributors and home delivery persons that supply games to gaming parlors, less affluent individual clients and shops in the urban periphery, small towns and villages. All of them are thought of as the nonelites. ${ }^{2}$ The problematic of talking of them as one community is countered by seeing them outside of the power, money and structural decision-making network of the elites (Butalia, 2013; Liang \& Sundaram, 2011). Statistically speaking the non-elites comprise the bulk of the Indian population. The informal and unorganized sector is about 90 percent of the Indian workforce. Indian Health Development Survey 20112012 lists only 2.7 percent of all households that are likely to have all of the five "middle class" consumables, a motor cycle, TV, a computer or laptop, a cooler or AC, and refrigerator. Ninety percent of the time the households have only a television set (Kundu \& Rathore, 2016) making the population attached to TV games considerably large in India.

In this article I will use fieldwork sources to recount the changes that the bazaars have undergone over the years and show they have refashioned themselves to meet the needs of a shifting consumer base.

\section{The Golden Age of the Bazaars of Video Games in India: 1980s and 1990s}

In the 1980s and 1990s, the electronic bazaars played a significant role in the gaming economy in India. They were the principal channels through which global video games entered the country. In the early days, the bazaars distributed video games to different commercial places in India and also to individual gamers. It was a time when Lajpat Rai Market, Palika Bazaar, and Nehru Place flourished equally because they found their niche markets and there were no immediate competitors to their legacy.

Lajpat Rai Market was established after India's Independence as a partition refugee rehabilitation market. It is a wholesale market that sells a variety of electronic products such as switches, VCR players, lights, and wires. In the 1980s, video games formed a part of the products using the network of importers and distributors already active in the market. In the early days, traders in Lajpat Rai Market kept Samurai Games, Sega handheld Games, Atari 2600, and Lara TV games. In the late 1990s, the market added PlayStation that were distributed to Palika Bazaar and other electronic markets in the city and smaller towns in the country.

Lajpat Rai Market became an important wholesale market of video games by nurturing links with individual importers, the "suitcase" entrepreneurs that went to Hong Kong, Bangkok, and Dubai and brought video games to the country (Sundaram, 2010). Many traders in Lajpat Rai Market point out that video games became part of the informal markets through the initiative of a few courageous and smart importers. 
Chandan's case is an example of how chance, individual effort, and intuition combined to make foreign video games a popular product in India. Quoting from field notes:

Chandan was born in a small town in Uttar Pradesh and until the early 1970s he owned a small restaurant in his hometown. A TV repair shop stood opposite to his restaurant. From time to time he would accompany Rakesh, the owner of the TV repair shop, to the houses of individual clients. He gradually gathered some information about repairing and his interest in electronics grew gradually. One day Rakesh left for Delhi looking for new job opportunities. He went on to join a TV company in Delhi. Meanwhile, Chandan found himself at a dead end in his life. He wanted a change in his trade, which would allow him to make more money. He decided to meet Rakesh in Delhi and see if there was any opportunity for him. In the late 1970s, the electronic markets in Delhi were already accustomed to individual importers who would take risks to bring new products into the local market. Rakesh suggested that Chandan could try his hand at being an importer. Chandan found the proposal of travelling abroad to get new electronic goods attractive. He had recently obtained a passport. The fear of travelling for the first time to a foreign land and the risk involved in smuggling goods did not deter him. Chandan decided to join a travel group to Hong Kong that Rakesh knew of. Once Chandan landed in Hong Kong, he was completely clueless. Only when the travel guide gave him tips on how to move around the city, did Chandan find the courage to explore on his own. Chandan memorized the routes to the electronic market, Shamshuipo in Hong Kong. Out of a range of products, video games caught his eye. They were already popular in Hong Kong and there were many parlours of arcade games in the city. The handheld video game was something new to Chandan. It was easy for him to carry them and he thought they could work in the local markets. As he predicted, handheld video games did very well in Delhi, so much so that on all the subsequent trips, Chandan concentrated on getting video games and gaming accessories. Chandan's trade met with great success. His passport was filled with visa stamps and there were no empty pages left in it. Throughout the ' 80 s and ' 90 s, Chandan travelled to a number of destinations, Honk Kong, Bangkok and Dubai that acted as centres of distributing of games manufactured in Japan and the West. With time, he gained the necessary confidence and became a pro at avoiding customs duties, and making necessary "settings" (arrangements) with officials. The range of goods he imported also widened, Chandan got TV games, portable video games, cartridges and adaptors.

Individual importers such as Chandan popularized video games in Lajpat Rai Market by bringing original games, copies, and hardware into the Indian market. They had an ingenious attitude and were courageous enough to surpass any hardships that they faced on their journey. One such problem was to get past the country's strong economic laws. What helped the importers to bring video games into the country were the "settings" (informal arrangements) with custom officials. The importers bribed many custom officials to allow them to smuggle video games into the country in quantities higher than what was permitted officially.

Traders in Lajpat Rai say in order to legally import goods into the country, one needed to pay customs duties as high as 300 percent on the actual price. The informal monetary arrangement with custom officials helped the importers to smuggle goods with lesser custom duties and in greater numbers than what was officially stipulated. The traders highlight that these were very delicate alliances and the importer had to be on his guard to not cross paths with new officials, with whom no prior "setting" had 
been made. The importers survived economically because of their risk-taking attitude and a trusty relationship that they developed with foreign traders, custom officials, and the locals, the traders in Lajpat Rai Market add.

In order to face a closed economy, Lajpat Rai Market in the 1980s was part of backyard innovation. While importers brought video games into the market, the quantities and prices were not suitable to meet the demand of video games in the local markets as well as that of outside Delhi. Many of the traders in the market made clones of NES (Nintendo Entertainment System) games. The Samurai gaming consoles was one such clone. The traders carefully assembled the chips of 9 IC (Integrated Circuit) boards in their shops. They imported the chips and the cartridges from China. The assembling and packaging was done in the local market. In this way, the traders at Lajpat Rai Market increased the quantity of gaming products.

Lajpat Rai Market with its suitcase entrepreneurs, informal monetary settings and backyard innovation were an unchallenged actor in the wholesale economy. It catered to traders in other markets such as Palika Bazaar. The market also targeted distributors that went to individual clients all over the city. Traders say that during those days, the market was so good that large quantities of video games would be sold out in no time. Prakash says when PlayStation 1 was launched in the late 1990s, his shop was one of the few that kept the product. Traders from different markets would pre-order so that they could lay their hands on the stock as soon as it arrived. He remembers truckloads of consoles unloaded in front of his shop and a crowd gathered to sort out and marvel at the new arrivals.

Alongside Lajpat Rai Market, Palika Bazaar was an important retail market. Established in the 1970s by the Delhi Development Authority, it was the first underground air-conditioned market in Delhi. It was an attraction both for local as well as foreign tourists. In the 1980s, video games became a part of its product range. Traders kept contraband games that attracted a range of consumer that could afford to buy video games, imported prices of which were quite high.

In the 1990s, Nehru Place occupied a special place in the gaming economy. It became popular as a market for computers. Since the 1990s, street vendors mainly from the slum rehabilitation in Madanpur Khaddar ${ }^{3}$ sold clothes, lamination services, and pirated software in front of the main buildings. Saurav, a street vendor in Nehru Place, says a consumer, after purchasing a computer, would look for other things that he could add on to his new computer. And one of the first things that they wanted was pirated software, he adds. Street vendors like Saurav made a good amount of money by downloading basic software such as Microsoft word and selling it for ₹200 or ₹300. He confesses sometimes noticing the demeanor of the consumer they charged even more. He remembers, consumers browsing through his stock of software would enquire about games. The queries about video games eventually encouraged the street vendors to include pirated computer games in their collection. Saurav explains as an additional purchase, pirated video games did well in the market. With time, even nongamers got interested in computer games seeing them lying among other DVDs.

In the 1980s and 1990s, gamers who could afford to have imported video games as an individual household possession came to the market; others were dependent on the gift network and the gaming parlors. As the traders mention, many of the people coming to buy games already had an IBM computer. Furthermore, alluding to the 
knowledge of the consumers, the traders say that many of them were part of the generation that read computer magazines such PC World to know about the latest games. This was not just the case with the urban elite but also the consumers who came to these markets from smaller towns. Consumers comprised a selective elite that had money and were part of a knowledge network that had updated information about the latest video game. Personal sources, whether it was imported magazines, relatives settled abroad or their own foreign tours, informed them about video games at a time when advertisements and mass media infiltration in the country was limited.

Lajpat Rai Market attracted distributors who wanted to capture the niche leisure market. They supplied games to shops targeting an expanding group of people in Delhi and outside who did not have problems in spending money to get hold of a product that was scarce in a closed economy. Palika was mainly catering to the households of businessmen and affluent local tourists who could afford to spend thousands of rupees. Naresh in Palika says, apart from a few gaming connoisseurs who saved up money to get, for instance, the Sega console, the market was crowded with people who spent a huge sum of money to simply boast of owning the latest console. With a narrow and risky supply network, video games carried Veblenian appeal of a conspicuous good that could set apart a consumer from the rest. Quite literally owning a video game was a cause of envy. A consumer remembers jealously eyeing the Atari console that a rich friend at his school had. Nehru Place also attracted a select group of designers and professionals that could pay as high as ₹5,000 to get Adobe Photoshop. Saurav, a street vendor, says that consumers came with their expensive computers and got architecture and other design software. He remembers them being very knowledgeable and he learnt a lot interacting with them.

The 1980s and 1990s stand out as the era in the bazaars when they attracted mostly the elite consumers. People who had money and updated information about imported games frequented a retail market like Palika. Lajpat Rai Market controlled the distributive network, it was in close contact with many individual importers who brought video games into the country and then circulated them in bulk among the traders in the market. The shops then sold out video games (at wholesale prices) to Palika and to individual distributors that catered to the moneyed elite outside of Delhi. Nehru Place attracted professionals that bought pirated software and computer games from the street vendors at a time when original DVDs were very expensive. As such all the three markets targeted a section of the population who had the knowledge of video games when the channels of information and acquisition network were limited. The former had to do with the limited reach and forms of media, and the latter had to do with a closed economy. The bazaars therefore, attracted consumers who were willing to pay a considerable sum of money to possess a smuggled console.

\section{New Actors in the Gaming Economy in India and Retreatment of the Bazaars: 2000s and 2010s}

Beginning from the late 1990s onwards, a number of new actors entered the gaming economy in India. The new entrants to the gaming economy adversely affected the bazaar economy. If we take, for instance, mobile gaming, especially the casual gamer 
would not come to the bazaars to buy games. He or she could get into his/her smart phones and download the latest games, most of which have a free trial period. In the 2000s, a new generation of mobile gamers has developed, playing Candy Crush Saga and Temple Run on their smart phones. The ubiquitous nature of mobile phone gaming created a new type of gamer and gaming economy in India, one that is more individualistic and not tied to a physical marketplace.

Another element that changed the shape of the gaming economy in India is the online market of games. E-commerce websites such as OLX and Flipkart sell new and used DVDs and consoles on their web pages. These websites guarantee the quality of the products and usually confirm that they do not sell pirated and stolen items. Also the websites manage to give a huge discount on their sales. All these facilities, along with free-home delivery, are making the online market of video games a viable option for many gamers to order video games at home.

The third challenge to the bazaars comes in the form of companies such as Sony and Microsoft that made foray into the Indian market via official distributors and repair centers. Apart from the presence of company actors, franchises of games were dominant in the gaming economy since the late 1990s. Milestone in New Delhi is an official franchise of video games of EA Sports, Capcom, and Sony. The company also has its own e-commerce site, Game4u.com, that reaches out to consumers in different parts of the country. With its collaboration, the company dominates formal places of gaming in the city. One afternoon in 2013, Jaideep, an employee of Milestone, speaks to me about how the company deliberately kept away from gray goods. He believes that the company had the advantage of starting back in 1997 when there was no problem of importing goods into the country. After the opening of the economy, Milestone could get company goods for a reasonable price. Jaideep argues that the situation was different for Palika. According to him, Palika made a lot of money when the traders sold contraband commodities for a fairly high price in the market. Jaideep is of the opinion that the quality and status depend on whether goods are brought from the bazaar or a company showroom. And he observes many young gamers today would prefer a company product to a gray one hampering the sales of a market like Palika.

The new actors in the gaming economy in India threaten the position that the bazaars have held so far. The innovative ways to import and distribute games from home delivery to online purchases affect the bazaars. Suddenly Delhi's bazaars that were not socially stigmatized had to face negative stereotyping. When the bazaars were the main actors of the gaming economy in India, not many questions were raised regarding their legitimacy. At that time, smuggling goods into the country, selling different varieties of the same product, both inferior and superior quality, was acceptable practice. Now with the malls and shopping complexes, the bazaars have become seedy places. Arvind, a trader from Palika Bazaar, argues that presently an elite gamer would come to the bazaars to buy games only when he has exhausted all other choices. According to him a setback for a market like Palika Bazaar is that traders do not generally bill products. This aspect makes many consumers assume that the market is full of cheats and is more likely to sell inferior quality than good products.

What Palika faces with the entry of official actors in the gaming economy is also true for Lajpat Rai Market. With companies having their own outlets and showrooms, it is unusual for them to approach Lajpat Rai Maket to showcase their latest releases. It is 
not a trend setting market anymore. Most of the times, a product reaches the market after it has run its course in other places. In this way it becomes the receiving point for products that face certain obsolescence elsewhere. Prakash's shop in Lajpat Rai Market that was in the late 1990s heaped with the latest PlayStation 1, in 2013 has a barren shelf with a handful of PlayStation $2 \mathrm{~s}$ and $3 \mathrm{~s}$.

With new actors entering the gaming economy in India even Nehru Place has seen a change in the consumer range and the way in which the market is perceived in the dominant discourse. Saurav, a street vendor in Nehru Place observes that in the 1990s no one spoke about piracy and the implementation of Copyright laws were skewed. Saurav is of the opinion that things changed drastically with the entry of Microsoft and other companies in the Indian market. He points out that often the local police raid their stock at the behest of complaints lodged by the Microsoft officials.

After the liberalization of the economy, in the 2000s and 2010s there is an entry of many new actors to the gaming economy: the online market, mobile phone gaming, and company distributors to name a few. Most of these actors are part of the formal economy and trade in company products coming with a warranty period. The bazaars, on the other hand, stand out as places that sell pirated and gray products. The elite consumers now go to showrooms, online market and official distributors, and buy original games with added services such as home delivery and warranty that bazaars do not usually provide.

\section{Bazaars as Open Places in the Twenty-first Century: The Entry Point of Non-elites into the World of Video Games}

In the last decade, the electronic bazaars have lost a lot in terms of the consumer range and the amount of profit they accumulate from their businesses. The elite consumers that form part of the NMC and business elites hardly come to the bazaars. As a trader points out, they go to posh shopping markets such as Khan Market in Delhi where they pay ₹1,000 to buy simple products such as mobile phone covers. The bazaars now cater more to the non-elite consumer. The non-elites are ignored to a large extent by the formal economy, which does not have a wide distributive network, and focus more on the major cities. Also the formal economy mostly works with standard price and product that do not suit the needs of the non-elite consumer in India. As such the bazaars, in the words of Michael Dertouzos, become radical places:

An image flashed before me-the Athens flea market. I knew it well. As a boy I had spent nearly every Sunday in its bustling narrow streets packed with people selling, buying, and trading every conceivable good. I was looking for electronics, especially illegal crystals with which you could build your own small radio station. Almost all of the people were friendly and talkative, tackling every conceivable topic between deals. They formed a community that stretched beyond its commercial underpinnings. There was no central authority anywhere; all the participants controlled their own pursuits. It seemed natural and inevitable to me that the future world of computers and networks would be just like the Athens flea market—only instead of physical goods, the commodities would be information goods.

(Michael Dertouzos as cited in Thorburn, 1998) 
Openness ${ }^{4}$ has always been a character of the bazaars. As Amal, a trader in Palika Bazaar observes unlike the malls there are no security guards at the entrance of the market, scanning the demeanor of each and every person. He knows personal stories of many friends and acquaintances, discouraged to enter the mall and meet the prying question of the security guard, "Apko kya chahiye?"(What do you want?) Amal mentions that one gets profiled in the mall and would be immediately cast as someone who does not belong (if not wearing the right kind of attire or shoes). According to him, on the contrary, the bazaar welcomes everybody. The interactions in the bazaar are not distant and formal. They are neither time-limited. Amal points out many conversations continue for hours moving from the state of the market to the political situation of the country. He asserts how a shop from the outside is noisy and crowded pulls even uninterested consumers inside it. To add to that, he speaks about the handful of young men that stand outside the shop trying to get the attention of the bystanders.

A usual scene in the bazaar is to see a trader and consumer playing a game on the same device. The trader explains to the consumer each step of the game as each held a joystick. The social exchange that starts with the trial of a product peaks during bargaining. Even though the information asymmetry is in most cases to the seller's advantage, it is rarely that a consumer lets the gap come in the way of bargaining. I have met consumers in all the markets that are comfortable asking any question to the trader, often times they are not aware of the product at all. One popular conversation opener is "Maine suna hain iss game ke bare mein, apke paas hain kya?" (I have heard about this game, do you have it with you?) Such a query leads the trader to show the consumer, for instance, the console Nintendo Wii. The consumer usually spends time scrutinizing the cover, asking many questions on the way, what kind of games one can play on it, how to play it, battery life, cost etc. After he/she is satisfied with the look of the product, he/she has been found to ask for cheaper and simpler items in the shop such as pirated DVD of Angry Birds. A consumer is more likely to buy a cheap product or most of the time nothing at all after a long interaction. This highlights the aspect of the bazaars as people-centric places. On the part of the consumers, it appears that they come to the bazaars with expectations exceeding the purchase. It may be a desire to see, hold, and play on a console. It could also be a way to kill time when one does not have much to do. The enthusiasm with which some consumers jump on to random conversations underway in the shop shows the tendency to do "timepass."

The traders see their enthusiastic consumer in a complex light. They would like their investment in the consumers to pay off each time. Their inability to do so is reconciled by maintaining a jovial atmosphere in the shop. There is a lot of leg pulling among the different traders in a shop; they circulate stories about consumers and entertain perceptions about the rich. Bharat, a trader in Lajpat Rai humorously remark,

You should see the traders at Select City Mall (an upscale mall in South Delhi), and they will not budge an inch from their seat. They have an air about them. After all the consumers are different, they do their research on the Internet and when they are at the shop, they just spot the product on the shelf and buy them. There is no bargaining. Not like here where we have to engage with the consumers for hours.

Govind in Palika Bazaar speaks about the consumers coming to the market, "half of them are mad and the other half clueless." He says that he gets consumers that ask him 
to show a couple of DVDs. And when he enquires them which game they prefer, they would say, "show me anything." Apart from the clueless sort, Govind identifies as "mad" those consumers who are overtly anxious. To quote from fieldwork notes:

One day at Palika, an evidently anxious consumer comes to Govind's shop. He asks for a Lara Croft DVD. Govind has it in his shop and quotes a price, which the consumer is not satisfied with. The consumer appears to be in dire need of the DVD. He runs a gaming parlour in West Delhi and he tells Govind that over the last couple of days many consumers returned because he could not provide them the DVD. Although Govind sees the urgency in the consumer, he does not bargain with him. He let the consumer try out other shops. On any other occasion, such a suggestion would be unheard of. The times that I spent at Govind's shop, it was unusual for him to recommend consumers to other shops unless he was sure that he could not procure the product. I am curious to know why Govind withdrew from the consumer without a bargain. To which he replies that he is sure the consumer is going to come back. Govind admits that he has a good mental map of the consumer, as he appears anxious, it is best to leave him unassisted. He thinks out of desperation the consumer would buy the product at the initial price. (As expected by Govind the anxious consumer returns to the shop approximately after twenty minutes and purchases the DVD at the quoted price.)

The intricate bargaining strategy opens up the bazaars as social spaces. As Govind analyzes the deep-rooted anxiety and vulnerability of each and every consumer that comes to his shop, he also gets to know him more closely as a person, and compiles new information about him with each new visit. The different actors in the bazaars in the process rarely exist as impersonal strangers. There are times, when Govind starts an exchange asking about the health of the consumer, why he was not visiting the shop for a length of time and about his family.

Govind's father represents the figure in the bazaars that is as much a trader as a great conversationalist. He is a retired army official and comes to his son's shop to help him in his trade. Most of the time though he is busy talking with the young assistants at the shop, the same shop having different traders selling toys, mobile accessories, and video games. He teases the young assistants saying that they are wasting away their lives by drinking and gambling. The young men respect Govind's father, enjoy his jovial nature, and also come to him for advices. As one of the consumers puts it, "I come to the shop to meet uncleji (Govind's father). He has gyan (wisdom) on different topics and he is such a delight to talk to. I always drop in to say hi."

Both Palika and Lajpat have the tradition of having dense relationship with their customers. Even with an irregular consumer, it is unlikely to see them jump straight on to commerce, unless there is a shortage of time. Otherwise most interactions are lazy, consumers browsing through the stacks at their pace, participating in the conversations already underway in the shop and if luck would have it partake in the tea and snacks arriving at the shop.

Among the two bazaars, Nehru Place attracts gamers that have the minimum knowledge and economic resources. The street vendors keep pirated DVDs $\backslash$ CDs of computer games, which means the consumers coming to the market are less likely to have moved on to the PlayStation generation. The street vendors do not find the utter lack of information among their consumers surprising. Many of them took to 
computers and games only after entering the market. Their humble backgrounds make them sympathetic to consumers with similar disadvantages. One day in Nehru Place two brothers come to buy a pirated DVD of Grand Theft Auto V. They work as delivery boys in a computer shop in Noida, a satellite city of Delhi. Handling computers for their clients got them interested in video games. Some years back they came to Nehru Place to buy their first PC. On their way home they had also installed some games from Saurav. The two brothers remember how they were clueless and Saurav mentored them on several occasions to get an understanding of video games. Saurav on his part is accustomed to gamers coming to him with no knowledge of how to download a game on the computer. He summarizes his meeting with inexperienced consumers as,

We are in a strange situation in the market. When you go to a bookstore for instance, you do not expect to get tuition (lessons) on the book you buy, but here we have to do that. We not only sell goods to consumers but also have to teach them how to use them.

Such a description stood out even more sharply when compared to the expert designers and architects that came to Saurav in the 1990s.

The aspect of the bazaars as people centric places does not only come through the attention and time that traders invest on each and every consumer. The distribution network of the bazaars continues to be wide and penetrative to the nook and cranny of the country that the official channels ignore. In recent years, Lajpat Rai Market's distribution network of games has become more prominent in the urban periphery in Delhi and other smaller towns in the country. Different distributors arrive at Vishal's shop at Lajpat Rai to buy video games. Ramesh is one such distributor who visits Vishal's shop regularly. He carries with him a worn out black bag in which he stores the video games. He prefers consoles that are below the range of ₹ 1,000 . At that price, Ramesh can have Chinese copies of handheld games. The knock-offs are the ones that he usually takes as he says his consumers are looking for a "use and throw variety." Ramesh targets the shops in less affluent neighborhoods in Delhi and makes door-to-door delivery.

At other times, Vishal's shop gets distributors from smaller towns. They would buy Sega and Samurai TV games. A gaming economy that is moving to highly sophisticated PlayStation 4 and Xbox One, many of these distributors are targeting households that do not have a computer. Many of these households are in far flung towns and TV games are what they could afford. As Vishal says referring to his present consumer range,

Delhi is not just about Connaught Place and South Extension. There are still places in Yamuna Vihar and the slums around it whose inhabitants do not have the money and information about the latest video games. Forget about information, they do not even have a proper electricity connection. These are the people we target.

He says that his consumers are more interested in having some basic experiences of playing video games than own the latest console in the market.

The bazaars in terms of the extrovert traders and their wide distributive network go a long way in making them open places. Furthermore, the existence of obsolete video games and small time innovation makes the bazaars suitable place of commerce for the non-elites. In summer 2013, Vishal's shop in the market was filled with cartridges of 
TV games and handheld video games. There were consoles of TV games, Chinese PVPs, adaptors, pieces of hardware on the selves. On the top shelf there were a few abandoned Xbox consoles. Local manufactures such as Sooroo games were also part of the paraphernalia of products. PlayStation Portable and Nintendo Game Boy existed alongside the cartridges of 8-bit games. In fact, the cartridges of Super Mario and Angry Birds took the maximum space in the shop. The arrangement of the shop is a perfect example of how the old products co-exist with the new. Parents walking with their young child trying to give him his first video games spot the "Made in China" handheld game with interchangeable cartridges. The hyper visibility of simple old games eschews the consumer from thinking that he is buying an antiquarian game; it appears that the game he prefers is the most popular one in the market. Even the trader does not show any special regard for the expensive consoles. The few original consoles appear mostly as show pieces; they lie in one corner of the shop. The trader is more interested in the cheap product that sells, often lining samples of it at the front of the counter hoping that would be the first thing that catches the consumer's eyes.

Lalit in his shop at Palika Bazaar modifies PlayStations to enable them to play new games. In this way, old consoles get a new lease of life playing DVDs that are otherwise only attached to the latest console. So far Palika has cracked until PlayStation 3. Each console after modding can play games from an upgraded version and also can play pirated games. The aspect of tinkering with the hardware of the motherboard (by including new chips that can upgrade the software of the machine) connects video games to consumers that are interested in the latest installation, but do not have the money to buy new consoles every three to four years. Lalit's shop is stacked with pieces of old and abandoned consoles that he uses to repair consoles, by replacing broken parts and adding new accessories and hardware. He gets many students and other young gamers. Their interactions are usually pedagogical. Lalit and his consumers talk about the different skills required to play a game, and what are the modifications made to the hardware of the new console. One day Lalit tells his consumer who is an engineering student, how he is reading through different hacking websites to understand the motherboard of Xbox One. At which point the consumer comes with his own knowledge about the console that he has learned as part of the course as a computer engineering student.

Govind has numerous second hand DVDs in his shop. Consumers come looking for second hand DVDs of video games, either those titles that are out of stock or those that are too expensive to purchase new. Govind carefully packages used DVDs with transparent paper so that they give at best an impression of the new and at the least appear in good working condition. The circulation of second hand games makes new DVDs old in no time. Often gamers would come to sell their used DVDs after having played it once. Although when a consumer gets a second hand DVD, it is already old in his eyes. However, at times Govind is able to manipulate his consumer and manages to pocket original price from an old DVD. This he does by packaging an old DVD in such a way that it is difficult to tell it apart from the new. He further puts fake price labels at the back of the plastic cover making it look brand new. The recycling of video games makes old games new, a new one old depending on the consequence of a transaction whether the trader is able to keep up the façade before a consumer or he has to acknowledge to its prior ownership. 
With a decline of elite consumers in recent years, the bazaars search for new avenues of profit. One way they do this is by targeting the non-elite consumers, who after the liberalization of the economy and advent of multiple media hear about video games, but do not have the knowledge or the money to spend on original games. The obsolete games in the form of cartridge, second hands, and cracked consoles appeal to consumers who cannot afford to buy brand new games from showrooms, and franchises. The social nature of the bazaars, that comes most vividly through bargaining, open them as unassuming places, where consumer can ask the most basic questions without feeling inferior. The presence of obsolete games and knock-offs together with the friendly demeanor of the trader has widened the market of games to the average consumer at a time when the mainstream economy of games identifies as its client only a small proportion of elite gamers.

\section{A History of Video Games through Bazaars}

Analyzing the history of video games through the lens of the bazaars, it comes to the fore, the contribution they make both in maintaining the bazaar-like "way of life" and also letting the materiality of the product be dynamic in its obsolescence. We see the participants in the electronic markets survive due to the social and gregarious nature of the traders and hybridity of the product. The first feature we saw developing through the physical layout out of the markets, free entrance and exit, hugely crowded and receptive to any type of consumer, rich or poor. Especially with the bargaining rituals these markets come alive and we see both the consumer and the trader valuing the interaction drawing into a successful transaction. On the part of the consumer, the friendly trader becomes a way to negotiate their own gaps of money and the knowledge they have about video games. The hyper visibility of video games in advertisements, movies, and social media gives enough awareness about the existence of the product, and the bazaars help the non-elites to come in direct contact with basic to sophisticated consoles and CDs/DVDs. Sociality on the part of the trader helps them to survive and get past the everyday obstacles of confronting new market actors, declining sales, and state surveillance.

Pushed by constraints the traders capture market niche left out by the formal economy. One such niche is the market that exists in less affluent neighborhood in the city, small towns, and villages in India. The other niche is the market for accessories and small time innovation around obsolete games. Ravi Sundaram's (2010) work focuses on this aspect and shows how out of survival concerns the bazaars in Delhi innovate. Especially with regard to media products, his work beautifully depicts how right from the pirate cassette culture in the 1990s, the cable television mashes up and the rhizomatic computer networks, these markets have survived state regulations by creating their own pockets of innovation and profit. His work also proceeds with a much needed caveat that much of the recent literature focusing on "jugaad," "an innovative fix," seems to be ignored. The management literature counts much of the street level innovation outside of a political universe (Rajdou, Jaideep, \& Simone, 2012). This is with regard to understanding how historically marginalized groups are forced to participate in "frugal and flexible" innovations as they lie outside a power network and 
decision-making process. The problem is also how frugal innovation, continues to struggle with the state that is increasingly moving toward neoliberal ideas and proprietary rights. Sundaram's (1999) work connecting innovation to the mass electronic markets also shows how elite "technoculture" is part of the fables of the state and belligerent Hindu nationalism. He highlights the highhandedness of the Indian state that reproduces colonial hierarchies of a modernist city where every kind of disorder including the "pirate" kingdom of media goods are swept under the carpet. Within this hostile economic and political environment, the bazaars are left with a few choices other than to innovate or face the consequence of falling out of the lucrative urban map.

The way in which Delhi's bazaars survive is by targeting the people that are left out by the formal economy of games: people with less money and information. The bazaars heighten the spirit of a people's place in order to welcome those who do not have indepth knowledge of video games and yet are curious about them. Also the bazaars target consumers that have knowledge about games but do not have money to buy them brand new. In both these cases, the presence of obsolete games and the small time innovations around them come a long way in connecting games with a diverse range of non-elite consumers. If one has an information lag about the latest video game, he can start by playing basic cartridge game and also can expect to get tips from the traders as to how to go about playing on a new console. If, on the other hand, a consumer wants to play PlayStation 3 DVDs but cannot afford them, he can mod his PlayStation 2 in the market. This way obsolescence is tied to the lived reality of different gamers in India and extends beyond the sentimental and aesthetic value that the media archaeology literature appears to focus. In the bazaars utility of old products take precedence over sentiments and aesthetic.

It is at the interstices of perennial struggle that bazaars become important actors in the economy with "quotidian" innovation toying with illegality. The innovations and also interactions are entrenched in the cultures of everyday life. Bazaars are in this sense Braudelian markets of "small profits" that are entangled with the longue durée of everyday life (Braudel, 1981). The rhythms of the everyday life in terms of the anecdotes, the backgrounds of traders and consumers, their fears and convictions make up the core of the commercial exchange.

With an increase in shopping malls and showrooms in cities, the bazaars (with their obsolete goods, flexible prices, and friendly assistance) are targeting the bulk of the Indian consumers excluded by formal and privatized places of consumption. The bazaars out of survival concerns consider the needs of the heterogeneous non-elites; they stand out as one of the few places that have not moved into a bland neoliberal culture of consumption.

\section{Notes}

1. Ravi Sundaram (2010) analyzes Palika Bazaar, Lajpat Rai Market, and Nehru Place having the sensibility of Mughal bazaars, crowded with dense networks of goods and people. Delhi's bazaars in the present time are well-connected market places with semilegal goods, informal payment procedure, and a decadent aesthetic.

2. The mass consumers of video games in the bazaars are mostly men (Doron \& Jeffrey, 2013). This is to do with the aspect that gamers in India are mostly male. There are a few "hardcore" 
female gamers; however, most female gamers are casual gamers playing on their smartphones, existing outside of a physical market place.

3. After the demolition of the slums in this area in 2001 to build a spiritual park (Batra \& Mehra, 2008) many of the families in the locality were rehabilitated in the Madanpur Khaddar as part of a Delhi Development Authority scheme, "Slum and JJ transit camps/rehabilitation."

4. "Openness" refers to its dictionary meaning as "unobstructed entrance and exit" to the marketplace. The aspect of sharing of knowledge and tools in the bazaars also falls within the frame of "openness" covered by the "access to knowledge" literature especially if we imagine it through the lens of open source and free software (Kapczmynski \& Krikorian, 2010).

\section{References}

Arora, S. (2014). India's video gaming revolution. The Sunday Guardian. Retrieved from http:/ / www.sunday-guardian.com/artbeat/indias-video-gaming-revolution

Batra, L., \& Mehra, D. (2008). The demolition of slums and the production of neoliberal space in Delhi. In M. Darshini (Ed.), Inside transforming urban Asia: Processes, politics and public action (pp. 391-414). Delhi: Concept.

Braudel, F. (1981). Civilisation and capitalism, 15th-18th century, I: The structures of everyday life. New York, NY: Harper \& Row.

Butalia, U. (2013). India's elite have a ferocious sense of entitlement. New Internationalist. Retrieved from https://newint.org/features/2013/01/01/india-elite-sense-of-entitlement/

Chatterjee, P. (2008). Democracy and economic transformation in India. Economic and Political Weekly, 43(16), 53-60.

Doron, A., \& Jeffrey, R. (2013). The great Indian phone book: How the cheap cell phone changes business, politics, and daily life. London: C Hurst \& Co.

Dyer-Witheford, N., \& Sharman, Z. (2005). The political economy of Canada's video and computer game industry. Canadian Journal of Communication, 30(2), 187-210.

Fanselow, F. S. (1990). The bazaar economy or how bizarre is the bazaar really? Man, New Series, 25(2), 250-265.

Fernandes, L. (2006). India's new middle class: Democratic politics in an era of economic reform. Minneapolis, MN, and London: University of Minnesota Press.

Fernandes, L., \& Heller, P. (2006). Hegemonic aspirations: New middle class politics and India's democracy in comparative perspective. Critical Asian Studies, 38(4), 495-522.

Geertz, C. (1963). Peddlers and princes: Social development and economic changes in two Indonesian towns. Chicago, IL and London: University of Chicago Press.

- (1978). The bazaar economy: Information and search in peasant marketing. American Economic Review, 68(2), 28-32.

Jain, K. (2007). Gods in the bazaar: The economies of Indian calendar art. Durham, NC: Duke University Press.

Kapczmynski, A., \& Krikorian, G. (Eds.). (2010). Access to knowledge in the age of intellectual property. New York, NY: Zone Books.

Kundu, T., \& Rathore, U. (2016). How can India bridge the gap between its middle and medianclass.Livemint.Retrievedfromhttp:/ / www.livemint.com/Opinion/uMcYLhhViH2IO X9jdzvHcM/How-can-India-bridge-the-gap-between-its-middle-and-median-c.html

Liang, L., \& Sundaram, R. (2011). India. In J. Karaganis (Ed.), Media piracy in emerging economies (pp. 339-398). California, CA: Social Science Research Council.

Parikka, J. (2012). What is media archaeology? Cambridge: Polity.

Rajdou, N., Jaideep, P., \& Simone, A. (2012). Jugaad innovation: A frugal and flexible approach to innovation for the 21st century. Noida: Random House. 
Saavala, M. (2010). Middle-class moralities: Everyday struggle over belonging and prestige in India. New Delhi: Orient Blackswan.

Sundaram, R. (1999). Recycling modernity: Pirate cultures in India. Third Text, 13(47), 56-65. . (2010). Pirate modernity: Delhi's media urbanism. New York, NY: Routledge.

Thorburn, D. (1998). This market, this bazaar of life: Markets imagined and remembered. Retrieved from http://web.mit.edu/m-i-t/articles/index_markets.html 